\title{
Empirical Study of Express Logistics Service Quality -A Survey of Changdao County Express Sector
}

\author{
Li Liu ${ }^{1, a}$, Chan Liü ${ }^{1, b}$ \\ ${ }^{12}$ School of Economics \& Finance, Hunan University of Technology, Zhuzhou, Hunan, 412007, \\ China \\ azwjll706@163.com, bmaga63lc@163.com
}

Key words: Express; Logistics service quality; SERVQUAL

\begin{abstract}
This study investigates the express logistics service quality in Changdao County by scales developed according to SERVQUAL and LSQ theoretical models. By exploratory factor analysis, the service quality scale yields five factors including reliability, protection, security, empathy and perception. Then, according to the differences between customers' expected and perceived values, this paper evaluates the express logistics service quality, and finds that customers place difference emphasis on the constructs, and the expected values are significantly different from the perceived ones. Finally, the implications of the research findings and suggestions are discussed.
\end{abstract}

\section{Introduction}

With the increase of market offerings of express delivery companies, logistics quality excellence has become an important source of competitive advantage. As of the first half of 2013, Chinese online retailing market scale reached 7542 billion RMB, online shopping customers reached 2.77 billion, national express service companies above designated size volume totaled 38.4 billion, an increase of 60.6\% [1]. However, the overall satisfaction of 2012 online express service is only 39.8\% [2]. In the pursuit of competitiveness, express companies are aware of the importance to identify the demands of customers. Traditionally, managers have paid much attention to moving and delivering parcels. But express logistics services can be leveraged to create more values for both companies and customers.

There are many definitions and descriptions of how logistics creates customer satisfaction, and scales developed have been used to qualify service performance [3-6]. Many researchers have adopted the service quality questionnaires known as SERVQUAL that pertain to the issues of service quality [7].

As announced by Taobao.com in 2012, the purchasing power of online shopping in counties and towns is higher than that in urban cities. As for Changdao County of Yantai City in Shandong Province, the average expenditure of online shopping was $6702.12 \mathrm{RMB}$, ranking the first among the counties of Shandong province [8].

The purpose of this research is to investigate the express logistics service quality in Changdao County by scales developed according to SERVQUAL and LSQ models. The results may enhance the knowledge about the customers and provide more information on the gap between customers' expectations and perceptions, which may be the sources of express logistics excellence.

\section{Research Design}

Changdao County is located on an island in Yantai City of Shandong Province, and its express sector is growing exponentially. However, the customer satisfactions are very low. As many researches studied customers of express sector in large cities, demands of those in counties are neglected. During this study, Changdao's business environment was becoming increasingly competitive as customers were given diversified choices in express service providers. Thus, the 
conclusions drawn in this research may help express companies improve the measurement and management of their logistics customer service in order to compete more effectively.

The study was accomplished by conducting a questionnaire survey. The first step was an effort to understand the logistics service quality needs of the customers of express companies in Changdao by interviews. Then, dimensions of the scale specific for this particular island county were developed, and survey instrument items were derived. Followed by modifications and a pre-testing, the scale of Changdao express logistics service quality was constructed, including reliability, responsiveness, flexibility, perception and empathy (25 items). All items used a standard 5-point Likert-type scale ranging from strongly disagree (1) to strongly agree (5).

The research team member distributed 220 questionnaires to the customers of express logistics providers in Changdao County. Finally, 181 questionnaires were collected and 137 were valid, representing the effective rate of $62.3 \%$.

Of the respondents, 73 of the respondents were male (53.3\%) and 64 were female $(46.7 \%)$. The majority of respondents (41.6\%) were of the age between 21 and 29. 26.4\% of the respondents used the service of Shentong, 26.0\% used Yuantong, 13.0\% used YunDa, and 12.0\% used EMS.

\section{Empirical analyses}

Exploratory factor analysis. First, the value of the KMO measure test is 0.916 , P value of Bartlett spherical test is .000 , showing that the sample data are suitable for factor analysis. The Cronach's alpha coefficient for each contract is higher than 0.800, and the total Crobach's alpha coefficient reaches 0.959 , representing acceptable reliability.

Principle component analysis (PCA) with Varimax rotation is used. Items with factor loadings of less than 0.500 , or items that do not load any factor or load on different factors are eliminated. Eigenvalue for all factors should be higher than 1. After deleting two items, five factors are extracted with the cumulative explained variance of $74.193 \%$, and are conceptualized as empathy, reliability, perception, protection and security (As shown in Table 1).

Table 1 Results of exploratory factor analysis

\begin{tabular}{|c|c|c|c|c|}
\hline Factor name & $\begin{array}{c}\text { Range of factor } \\
\text { loading }\end{array}$ & Eigenvalue & $\begin{array}{c}\text { The cumulative explained } \\
\text { variance (\%) }\end{array}$ & $\begin{array}{c}\text { Crobach's } \\
\text { alpha }\end{array}$ \\
\hline Empathy(6 items) & $0.673-0.892$ & 12.761 & 19.653 & 0.918 \\
Reliability (7 items) & $0.558-0.788$ & 2.117 & 37.884 & 0.922 \\
Perception (5 items) & $0.697-0.803$ & 1.553 & 54.899 & 0.928 \\
Protection (3 items) & $0.609-0.829$ & 1.075 & 65.186 & 0.811 \\
Security(2 items) & $0.821-0.830$ & 1.043 & 74.193 & 0.801 \\
\hline
\end{tabular}

Weight determination. Based on factor analysis, we further determined the weights of each construct. First, 87 customers were selected to score the importance of express logistics service quality ranging from 1 to 5, then the mean of each construct was obtained. The result was: Reliability(4.616) $>$ Protection(4.554) $>$ Security(4.458) $>$ Empathy(4.265) $>$ Perception(4.170). Finally, multiplication scale method was used to determine the weights of the dimension [9] (As shown in Table 2).

Factor loading in the rotated factor loading matrix was selected to decide the specific weight of each item. The normalized processing was used to make $\sum_{i}^{m} W_{i}=1$ for the factor loading of specific item.

\section{Evaluation of express logistics service quality}

Data analysis. According to the formal express service quality rating system of Changdao County, a total of 300 questionnaires were issued once again. Later, 236 questionnaires were got and 199 questionnaires were valid (the effective rate of 66.3\%). 
Through the sample data analysis, the means of expected and perceived values are got (as shown in Table 2). The least five differences are $\mathbf{u}_{19}, \mathbf{u}_{12}, \mathbf{u}_{21}, \mathbf{u}_{20}$ and $\mathbf{u}_{3}$, while the top five differences are $\mathrm{u}_{10}, \mathrm{u}_{18}, \mathrm{u}_{5}, \mathrm{u}_{6}$ and $\mathrm{u}_{15}$, indicating the problems by express companies now.

Table 2 Express customer expected-perceived values

\begin{tabular}{|c|c|c|c|c|c|c|c|}
\hline Dimension & $\begin{array}{c}\text { Weight } \\
\left(W_{y}\right)\end{array}$ & Specific index & $\begin{array}{c}\text { Weight } \\
\left(W_{y e}\right)\end{array}$ & $\begin{array}{c}\text { Mean of } \\
\text { expected } \\
\text { value }\end{array}$ & $\begin{array}{l}\text { Mean of } \\
\text { perceived } \\
\text { value }\end{array}$ & Difference & $\begin{array}{l}\text { Sort } \\
\text { order }\end{array}$ \\
\hline $\begin{array}{c}\text { Reliability } \\
\left(Y_{1}\right)\end{array}$ & 0.335 & \begin{tabular}{|l|}
$\mathrm{u}_{1}$ Timely arrival reminding \\
$\mathrm{u}_{2}$ Sending(receiving) timeliness \\
$\mathrm{u}_{3}$ Sending(receiving) accuracy \\
$\mathrm{u}_{4}$ Updating information timely \\
$\mathrm{u}_{5}$ Express processing when the \\
weather doesn't allow navigation \\
of the ship \\
$\mathrm{u}_{6}$ Shipping express protection \\
$\mathrm{u}_{7}$ Error handling capacity
\end{tabular} & $\begin{array}{l}0.169 \\
0.152 \\
0.151 \\
0.141 \\
0.134 \\
0.134 \\
0.120\end{array}$ & $\begin{array}{l}4.640 \\
4.547 \\
4.587 \\
4.440 \\
4.347 \\
4.573 \\
4.600\end{array}$ & $\begin{array}{l}3.920 \\
3.867 \\
4.053 \\
3.787 \\
\\
3.480 \\
\\
3.720 \\
3.773\end{array}$ & $\begin{array}{l}-0.720 \\
-0.680 \\
-0.534 \\
-0.653 \\
-0.867 \\
-0.853 \\
-0.827\end{array}$ & $\begin{array}{l}21 \\
20 \\
18\end{array}$ \\
\hline $\begin{array}{l}\text { Protection } \\
\quad\left(Y_{2}\right)\end{array}$ & 0.248 & \begin{tabular}{|l}
$\mathrm{u}_{8}$ Claims timely and reasonable \\
$\mathrm{u}_{7}$ Complaint handling \\
$\mathrm{u}_{10} \begin{array}{l}\text { Reasonable price (land and } \\
\text { water transportation) }\end{array}$ \\
\end{tabular} & $\begin{array}{l}0.380 \\
0.340 \\
0.280\end{array}$ & $\begin{array}{l}4.520 \\
4.413 \\
4.760\end{array}$ & $\begin{array}{l}3.707 \\
3.653 \\
3.707\end{array}$ & $\begin{array}{l}-0.813 \\
-0.760 \\
-1.053\end{array}$ & $\begin{array}{l}17 \\
15\end{array}$ \\
\hline $\begin{array}{l}\text { Security } \\
\quad\left(Y_{3}\right)\end{array}$ & 0.183 & $\begin{array}{l}\mathrm{u}_{11} \text { Personal information security } \\
\mathrm{u}_{12} \text { Social service security }\end{array}$ & $\begin{array}{l}0.503 \\
0.497\end{array}$ & $\begin{array}{l}4.533 \\
4.333\end{array}$ & $\begin{array}{l}3.987 \\
4.067\end{array}$ & $\begin{array}{l}-0.546 \\
-0.266\end{array}$ & $\begin{array}{l}6 \\
2\end{array}$ \\
\hline $\begin{array}{l}\text { Empathy } \\
\quad\left(Y_{4}\right)\end{array}$ & 0.135 & $\begin{array}{l}\mathrm{u}_{13} \text { Providing door-to-door service } \\
\mathrm{u}_{14} \text { Personalized care } \\
\mathrm{u}_{15} \text { Active willingness to help } \\
\quad \text { customers } \\
\mathrm{u}_{16} \text { Diversity in distribution } \\
\mathrm{u}_{17} \text { Focusing on clients' interests } \\
\mathrm{u}_{18} \text { Understanding customer needs }\end{array}$ & $\begin{array}{l}0.199 \\
0.174 \\
0.172 \\
0.154 \\
0.151 \\
0.150\end{array}$ & $\begin{array}{l}4.080 \\
4.000 \\
4.227 \\
4.160 \\
4.213 \\
4.253\end{array}$ & $\begin{array}{l}3.284 \\
3.267 \\
3.390 \\
3.453 \\
3.467 \\
3.373\end{array}$ & $\begin{array}{r}-0.796 \\
-0.733 \\
-0.837 \\
-0.707 \\
-0.746 \\
-0.880\end{array}$ & $\begin{array}{l}11 \\
14 \\
22\end{array}$ \\
\hline $\begin{array}{c}\text { Perception } \\
\quad\left(Y_{5}\right)\end{array}$ & 0.099 & \begin{tabular}{|l}
$\mathrm{u}_{19}$ Staff image \\
$\mathrm{u}_{20}$ The staff service attitude \\
$\mathrm{u}_{21}$ Office facilities in good \\
condition \\
$\mathrm{u}_{22}$ The staff knowledge level \\
$\mathrm{u}_{23} \begin{array}{l}\text { Standardization of employee } \\
\text { jobs }\end{array}$
\end{tabular} & $\begin{array}{l}0.212 \\
0.206 \\
0.203 \\
0.195 \\
0.184\end{array}$ & $\begin{array}{l}3.680 \\
4.413 \\
3.907 \\
4.293 \\
4.480\end{array}$ & $\begin{array}{l}3.587 \\
3.880 \\
3.467 \\
3.680 \\
3.867\end{array}$ & $\begin{array}{r}-0.093 \\
-0.533 \\
-0.440 \\
-0.613 \\
-0.613\end{array}$ & 1 \\
\hline
\end{tabular}

Service quality calculation. According to the above data analysis and SERVQUAL model, the average customer expectations (ACE) and average customer perceptions $(A C P)$ are calculated. Then, the score of express logistics service quality (ELSQ) is calculated. The results are as followed.

$$
\begin{aligned}
& A C E=\sum_{y=1}^{n} W_{y} \sum_{e=1}^{t} W_{y e} \bar{Q}_{e}=4.432 . \\
& A C P=\sum_{y=1}^{n} W_{y} \sum_{e=1}^{t} W_{y e} \bar{G}_{e}=3.750 .
\end{aligned}
$$




$$
E L S Q=\sum_{y=1}^{n} W_{y} \sum_{e=1}^{t} W_{y e}\left(\bar{G}_{e}-\bar{Q}_{e}\right)=-0.682 .
$$

Where $W_{y}$ means the weight for each construct; $W_{y e}$ means the weight for each item of each construct; $n$ means number of constructs; $t$ means number of specific items.

\section{Results analysis}

Generally speaking, the mean of customer expectations is 4.432, but that of perceptions is 3.750 . Total score of actual express logistics service quality was -0.682 , less than 0.000 . By means of paired sample $\mathrm{T}$ test about expectation and perception values, the result shows a significant difference (sig.<0.05). It means that there is a big gap between the customers' expectations and perceptions, which leads to customer dissatisfaction. (As shown in Table 3)

Table 3 The paired samples T test

\begin{tabular}{|c|c|c|c|c|c|c|c|c|}
\hline \multirow{4}{*}{$\begin{array}{l}\text { Expectation } \\
- \\
\text { Perception }\end{array}$} & \multicolumn{5}{|c|}{ Paired difference } & \multirow{3}{*}{$\mathrm{t}$} & \multirow{3}{*}{$\mathrm{df}$} & \multirow{3}{*}{$\begin{array}{c}\text { Sig. } \\
\text { ( bilateral) }\end{array}$} \\
\hline & \multirow[t]{2}{*}{$\begin{array}{l}\text { Mean } \\
\text { value }\end{array}$} & \multirow[t]{2}{*}{$\begin{array}{l}\text { Standard } \\
\text { deviation }\end{array}$} & \multirow[t]{2}{*}{$\begin{array}{c}\text { Standard error } \\
\text { of the mean }\end{array}$} & \multicolumn{2}{|c|}{$\begin{array}{c}\text { The difference } \\
\text { of the } 95 \% \text { confidence } \\
\text { interval }\end{array}$} & & & \\
\hline & & & & Lower limit & Upper limit & & & \\
\hline & 0.646 & 0.205 & 0.091 & 0.392 & 0.900 & 7.063 & 4 & 0.002 \\
\hline
\end{tabular}

The result shows as followed: $Y_{3}($ Security $)>Y_{5}$ (Perception) $>Y_{1}($ Reliability $)>Y_{4}($ Empathy $)>Y_{2}$ (Protection). Among them, the biggest difference is reflected in $Y_{2}$ (Protection). Changdao County is located on an island, and the water transportation is the weakness of the logistics service. From interviews, we learn that customers are dissatisfied with additional charge. Problems in the protection and management of marine section were the main reason resulting in such a considerable gap in $Y_{1}$ (Reliability), on the one hand, parcels couldn't be well packed in order to avoid moist, damage and pollution, on the other hand, express providers couldn't make plans in time to avoid such problems of delays caused by wind or fog. Meanwhile, the minimum differences are reflected in $Y_{3}$ (Security) and $Y_{5}$ (Perception), which indicates that customers are generally satisfied with the two dimensions, mainly reflected in $\mathrm{u}_{12}, \mathrm{u}_{19}, \mathrm{u}_{20}$ and $\mathrm{u}_{21} ; Y_{4}$ (Empathy) which ranked fourth on the difference, indicating that customers were not satisfied with it. By interviews with customers, the main complaints come from the less customized services provided by the companies, for example, they don’t provide door-to-door services.

\section{Conclusion}

Three helpful conclusions could be drawn from this study. First, service quality scale of express logistics providers in Changdao County is conceptualized as five constructs: reliability, protection, security, empathy and perception. Second, the weight of each constructs is determined as followed: Reliability $>$ Protection $>$ Security $>$ Empathy $>$ Perception. Third, the empirical results show that the expected values of customers are significantly different from the perceived values, showing that customers are not satisfied with the service quality of express logistics providers in Changdao.

Based on the above conclusions, the express logistics quality is a complex concept that addresses these five components, which demands a great deal of attention and efforts from companies. This study also finds that express logistics quality is a process where customers' perceptions begin to form and develop from the order placement to service completion, and they may place difference emphasis on the service quality. Therefore, it is imperative for express providers to identify and assess the weights their customers place on the constructs. Furthermore, they should pay more attention to the weakness such as the shipping link, claims and freight, lack of door-to-door 
service and customer complaints.

Two important study limitations should be presented. First, the scale developed in this study may need further testing. Second, the sample in this study was drawn from Changdao County, thus, the conclusions inferred may not be generalized to other regions.

\section{References}

[1] Information on http://www.100ec.cn/detail--6111486.html

[2] Information on http://www.chinawuliu.com.cn/zixun/201210/17/187977.shtml

[3] J.T. Mentzer, D.J. Flint and G.T.M. Hult: Journal of Marketing. Vol.65 (2001), p. 82-104

[4] C.C. Bienstock, M.B. Royne, D. Sherrell, et al: International Journal of Production Economics. Vol.113 (2008), p.205-222

[5] F. Lv, Z.W. Guo and X.Z. Jia: Industrial Engineering. Vol.12 (2009), p. 91-94

[6] B.L. Liu, Y.R. Zhang: Logistics Technology. Vol.30 (2011), p. 1-3

[7] A. Parasuraman, V.A Zeithaml and L.L. Berry: Journal of Retailing. Vol.64 (1988), p. 12-40

[8]Information on http://sd.ifeng.com/news/fengguanqilu/detail_2013_07/31/1055200_0.shtml

[9] Z.Z. Li: Master's thesis submitted to Dalian University of Technology (2013) 